\title{
Arbor
}

\section{Teatro y cine: un permanente diálogo intermedial}

\author{
José Antonio Pérez Bowie
}

Arbor CLXXVII, 699-700 (Marzo-Abril 2004), 573-594 pp.

Se intenta trazar una panorámica de las aportaciones teóricas más significativas sobre las relaciones entre teatro y cine, con especial atención a algunas de las producidas recientemente en el ámbito español. En un primer apartado se lleva a cabo un recorrido somero sobre los principales problemas que plantea el cotejo de ambos medios y en los dos siguientes se abordan respectivamente los problemas planteados por adaptación de los textos teatrales al cine y la influencia ejercida por éste, a partir de determinado momento de su desarrollo, sobre el arte escénico. Este último apartado se completa con el análisis, a título de ejemplo, de un caso concreto: la producción de los comediógrafos de la denominada «la otra generación del 27».

\section{Las relaciones entre teatro $y$ cine}

Un repaso a la historia de las teorías cinematográficas basta para poner de manifiesto la complejidad de las relaciones entre estos dos medios de expresión artística y las actitudes, a menudo encontradas, que con respecto a las mismas han venido manteniendo quienes han pretendido una caracterización de ambos. Contamos con resúmenes excelentes de tales propuestas teóricas (por ejemplo, Guarinos, 1992) que me permiten prescindir de una exposición pormenorizada y sistemática. Entre dichas propuestas se encuentran muchas prematuramente envejecidos a causa 
de la rápida evolución del nuevo medio o debido a la temprana caducidad de los presupuestos metodológicos de los que partían, por lo que su interés resulta hoy exclusivamente arqueológico; pero a su lado coexisten otras que dan señales de la vitalidad y el rigor intelectual entre los que se desenvolvieron tales reflexiones y constituyen un testimonio sobre la evolución del cine imprescindible para comprender su afianzamiento como medio de expresión artística independiente.

Señalemos para entrar con rapidez en materia, cómo en un principio, la preocupación principal de los teóricos se centró en torno al problema de deslindar los territorios de ambos medios, lo que significa, como apunta Guarinos, que estaban lo bastante implicados para necesitar esa diferenciación (Guarinos, 35). No hay que olvidar que el cine nace como un espectáculo teatral más y formando un todo indisoluble con el mundo de las varietés, por lo que se integra en un contexto enormemente amplio en el que convive con fórmulas muy diferentes (prestidigitación, magia, circo, canciones, etc.) de las cuales recibe préstamos tanto temáticos como escénicos (Abuín, 25; Hueso, 48).

Esa dependencia evidente del espectáculo teatral se observa en el mimetismo con que los filmes primitivos incorporan los mecanismos de expresión escénica (adopción por la cámara del punto de vista del espectador de la sala, escena calcada de la teatral con los actores de pie y vueltos hacia el público) e incluso sus fórmulas de presentación de la historia, pues muy tempranamente el cine recurre a la construcción de un universo simplificado tomado directamente del melodrama teatral: oposición de principios contrapuestos (deber / pasión, lealtad / amor, odio / perdón), tipificación extrema y esquematismo de personajes y situaciones, etc. No obstante, el cine comienza pronto a andar el camino que lo alejará de los modelos teatrales: el desarrollo de los filmes cómicos, basados fundamentalmente en los gags visuales, propician en los Estados Unidos el desarrollo de un arte específico que, aparte de liberarse de las servidumbres literarias, elabora un modo de contar inspirado en los esquemas de la narración clásica y diferenciado con nitidez de la «mostración» teatral; esa revolución de la que nace el cine moderno es posible gracias a la incorporación de hallazgos expresivos como la variación de la distancia entre el espectador y la escena, la subdivisión de la escena completa en imágenes aisladas, la variación del encuadre y, sobre todo, el montaje. La ausencia de sonido en las primeras etapas del cine está, sin duda, en el origen de esta evolución del nuevo medio que le hizo alejarse de los modelos teatrales al tener que buscar un lenguaje sustentado exclusivamente sobre la imagen. 
El afianzamiento del cine como arte específico y dotado de un lenguaje propio no implica, sin embargo, una ruptura total con el arte escénico pues las relaciones entre ambos se mantendrán de modo permanente, si bien con periodos de mayor o menor fluidez, en un diálogo mutuamente enriquecedor. Por ejemplo, y de modo paradójico, la falta de palabra se compensaba durante todo el periodo silente y aún en los primeros tiempos del sonoro, mediante la exageración de la mímica y de la gestualidad que procedían sobre todo del melodrama y de la pantomima (Relinger, 133). Por otra parte, cuando superada su etapa de atracción verbenera y ante la urgencia de captar públicos más selectos, el cine necesita de un cierto reconocimiento artístico, su referente más inmediato es el teatro: recuérdese, al respecto, cómo la tradición francesa del llamado «film d'art» se inicia en una fecha tan temprana como 1908 con la adaptación de L'assesinat du Duc de Guise, un intento de transformar el cine en un medio artístico a la altura de los medios literarios tradicionales; el éxito del experimento francés lleva al cine norteamericano a reeditarlo y así Zukor produce la serie «Famous players in famous plays» cuyo objetivo, era igualmente el de atraer a las salas de exhibición a la burguesía interesada en la cultura. Y por citar un último ejemplo, perteneciente aún a la etapa primitiva del cine, piénsese en la impregnación de teatralidad que experimenta la cinematografía expresionista alemana en la que las matizaciones y contrastes de la luz se convertían en un elemento definidor de los decorados y ambientes y en donde los atormentados personajes se expresaban con gestos de una excesiva grandielocuencia ${ }^{1}$.

La adquisición de la palabra por parte del cine supone otro momento de revitalización de las relaciones entre ambos medios: la pantalla comienza a competir en igualdad con la escena, produciéndose una fructífera incorporación de elementos y recursos procedentes de la segunda que contribuyeron, sin duda, al perfeccionamiento del lenguaje cinematográfico, aunque, como luego se verá, esa influencia opera también en sentido inverso. Entre los recursos de procedencia teatral que el cine incorpora a partir de ese momento se pueden citar la utilización dramática del texto y de la palabra, la transformación del espacio en escena cerrada, los decorados transpuestos, la interpretación de los actores a imitación de los del teatro, la focalización que privilegia el punto de vista de un espectador del patio de butacas, el uso de la cámara frontal y fija que filma amplios planos de conjunto, las mises-en-abyme, etc., por no hablar de los innumerables préstamos temáticos. Podría decirse que con la adquisición de la palabra el montaje deja de ser la categoría estética dominante y queda supeditado al desarrollo lógico de la trama, la cual se 
torna más transparente a la vez que comienza a dar cabida a contenidos de tipo psicologista.

El proceso de teatralización experimentado a partir de la adquisición de la palabra adquiere una especial intensidad en determinados momentos de la historia del cine. Uno de ellos afecta a la producción norteamericana de la década de los 50 y puede ser explicado en parte por motivaciones de índole sociológica: la sensación de frustración y desolación de un mundo que no consigue superar los traumas de la postguerra y la profundización en los cońflictos psicológicos padecidos por quienes participaron en la contienda afloran en muchos filmes de la época en los que se presta una atención especial al estudio de la psicología de los personajes, seres cotidianos que transmiten una serie de desequilibrios y traumas que reflejan la complejidad de su existencia y son paradigmas de la llamada crisis del sueño americano (Hueso, 55-56). Tales filmes son, en muchos casos, adaptación de textos teatrales contemporáneos (Arthur Miller, William Inge, Tennessee Williams), pero en otros proceden de guiones originales a partir de los cuales los realizadores elaboran un discurso fílmico que se aleja de la narratividad clásica y asume muchas de las estrategias de la puesta en escena teatral. Nos hallamos ante lo que Virginia Guarinos define como "cine teatralizado", intermedio entre el cine narrativo y el cine poético, que supondría una mengua de la narratividad, aunque no ha de tener como base necesariamente un texto teatral previo (Guarinos, 63): el montaje cede su protagonismo a la puesta en escena por lo que predominaran los planos secuencia, el uso de la profundidad de campo, el movimiento interno, etc. ${ }^{2}$.

Respecto del nivel temático cabe recordar para este tipo de filmes la descripción que Kracauer hace de los denominados «argumentos teatrales» y que se caracterizan, por una parte, por el énfasis en la interrelación humana representado sólo aquellas partes del universo real basadas en el diálogo y en la actuación y creando a partir de ello una intriga que inevitablemente se centra en sucesos y experiencias humanas; otra de las características apuntadas sería la de «totalidad dotada de propósito», dado que este tales argumentos desdeñan toda imagen que no contribuya al desarrollo del drama y sólo retiene aquello que puede convertir en inteligible su propósito; el argumento teatral, dirá, gira alrededor de un centro ideológico hacia el cual convergen todos sus modelos de significado (Kracauer, 274-275).

Otro momento en que la influencia de lo teatral sobre el medio cinematográfico se pone especialmente de manifiesto serían las últimas décadas con el desarrollo de la llamada teatralidad postmoderna. Se trata ahora de enfatizar consciente y deliberadamente las marcas definidoras 
Teatro y cine: un permanente diálogo intermedial

de lo teatral: artificiosidad de la escenografía, interpretación desmesurada de los actores, explicitación del proceso y acto de enunciación, etc. Óscar Cornago llama la atención sobre está tendencia de varios realizadores actuales, precisamente en el momento en que el arte escénico parece haber renunciado a las estrategias de recuperación y enfatización de sus elementos específicos (la «reteatralización» que se impuso en la escena occidental desde comienzos del siglo XX y marca toda las grandes realizaciones hasta casi sus últimas décadas) para cultivar la vía «postdramática» poniendo de relieve los aspectos performativos y perceptivos en un intento de proporcionar la transparencia y la autenticidad como medio más eficaz de expresar las utopías y angustias del hombre contemporáneo (Cornago, 553-554). Basándose en las teorías de Lyotard (1981) sobre el fenómeno de la teatralidad postmoderna, Cornago subraya cómo el cine contemporáneo acude a ella para superar la crisis de credibilidad sufrida por la retórica hollywoodense (la famosa transparencia enunciativa del cine clásico) y la inflación de imágenes que padece la sociedad actual: «a través del espacio abierto por la teatralidad mediante la mostración de los medios de rodaje, los escenarios o los procesos de filmación se ha intentado recuperar la condición de realidad perdida del medio cinematográfico, la debilitada credibilidad de las imágenes en una sociedad de la imagen» (Cornago, 554) ${ }^{3}$. Los ejemplos citables serían numerosos desde el último Fellini a Peter Greenaway, Daniel Huillet o Jean Marie Straub en cuyos filmes encontramos una exacerbación de la teatralidad, de la puesta en escena fílmica a partir de homenajes a la ópera, al cabaret o al gran guiñol; aunque Cornago utiliza como ejemplificación las películas musicales de Carlos Saura en las que la teatralidad se convierte es estrategia para recuperar una impresión de realidad en formas culturales y lenguajes artísticos fuertemente estereotipados; con ello se lleva a cabo una denuncia de la falsedad de las historias representadas, expuestas como procesos de montajes de un espectáculo, frente a la realidad performativa de su acto de construcción escénica y fílmica (Cornago 555).

Hay que tener en cuenta, por otra parte, la frecuencia con que el cine a lo largo de su historia ha recurrido a la inserción de interludios teatrales con la finalidad de poner de relieve, por contraste, el flujo de la vida «real» distanciándose de él, para evidenciar la «naturalidad» del universo en que transcurre la historia. Para Kracauer tales insertos llevan a cabo una función estética positiva pues realzan lo no escenificado: la ilusión teatral se derrumba a la vez que se apela a ella para transmitir por contraste el encanto de la vida no adulterada. El ejemplo que aduce es sumamente revelador: la secuencia de Le million, de René Clair, en don- 
de se contrasta la escena amorosa que interpreta una pareja de actores en una representación operística con la que vive la pareja de jóvenes espectadores sentados en un rincón de la sala (Kracader, 105-106).

Cabría referirse para cerrar este apartado a los intentos de delimitar los ámbitos de ambos medios, que constituyen una importante parte del abundantísimo corpus teórico surgido tras la aparición del cine. Dentro de dicho corpus se pueden encontrar algunas posiciones que tratan de sostener la absoluta indistinción entre cine y teatro, como la de Carlo Ludovico Raghianti, quien partiendo de una concepción espectacular del teatro, lejana de toda base literaria, y que hace de él un arte esencialmente visual $\mathrm{y}$, por tanto, figurativo, sostiene que ambos «son manifestaciones de un lenguaje formal, unitario y conforme» (Aristarco, 69). Pero salvo alguna excepción como ésta, la tendencia general es a sentar las bases de la especificidad de cada medio y a delimitar con precisión sus respectivos ámbitos. No es momento de extenderse en la exposición de los argumentos aducidos (Nicoll, Bazin, Sontag, Helbo, Bettetini, etc) sobre el que existen síntesis recomendables (Guarinos, 1996; Abuín, 2001), aunque sí señalar que un concepto tan debatido como el de realismo ha sido invocado a menudo en tales debates hasta el punto de convertirse en un recurrente caballo de batalla. En otro lugar me he ocupado de seguir la polémica sobre tal cuestión en España en el periodo de preguerra (Pérez Bowie, 2004a), por lo que me limitaré a citar algunas reflexiones posteriores y formuladas desde otros ámbitos. Recuérdese, por ejemplo, la de Peter Brook relativa al déficit de realidad que implica el teatro frente al cine, lo cual exige un pacto comunicativo más fuerte con el espectador ya que éste no tiene dificultades para construir la «realidad» a partir de meras insinuaciones; de ahí que «en el teatro la imaginación llena el espacio, mientras que la pantalla de cine representa el todo y exige que todo lo que aparece en la imagen esté relacionado de una manera lógica y coherente. El vacío del teatro permite que la imaginación rellene los huecos» (Brook, 38).

Por su parte, André Bazin sostiene que la ilusión del cine deriva, paradójicamente, de su mayor "realismo» frente a la fuerte convencionalidad del teatro que exige la aceptación de unas reglas que obligan a distinguir el lugar escénico de la realidad. Por eso, el espectáculo teatral no se confunde con la naturaleza mientras en el cine la realidad y la pantalla forman un continuum que no exige ningún esfuerzo a la voluntad del espectador para aceptar la ilusión cinemática y propiciar los mecanismos identificativos (Bazin, 154).

Citemos, por último a André Helbo quien insiste en que mientras la labor del director de escena se lleva a cabo fundamentalmente rellenan- 
Teatro y cine: un permanente diálogo intermedial

do los intersticios interpretativos abiertos por el texto, esta operación resulta excepcional en el cine donde el universo de referencias del espectador tiene sus raíces en la ficción expuesta, la cual sólo será creíble si privilegia las leyes de la verosimilitud narrativa. Ello se debe a que el cine tiende a borrar la función enunciativa y a privilegiar el relato, lo cual se traduce en un efecto de modalidad asertiva, incluso de naturalización: por eso, si el teatro puede sacar partido del catón-piedra y erigirlo en símbolo, el cine escoge más a menudo el efecto-verdad y enmascara el cartónpiedra para insertarlo en la verosimilitud; al contrario de lo que sucede en el teatro, la imitación debe ser siempre perfecta, inscribirse -señala citando a Bazin- en una relación de conformidad con lo real (Helbo, 54).

\section{Del teatro al cine. Problemática de la adaptación. Tipología}

Abordar la problemática de las relaciones entre teatro y cine exige dedicar una especial atención al caso de la adaptación fílmica de textos teatrales. Sobre este aspecto, como sobre el fenómeno de la adaptación en general, la teoría contemporánea ha superado los enfoques estructuralistas limitados a los enunciados (y, por ello, exclusivamente intratextuales) y pone el acento en el proceso material de realización, en los mecanismos de producción significante, más que en los significados producidos en tales procesos. Gran parte de las aproximaciones teóricas actuales tienden, pues, a abordar el fenómeno de la adaptación insistiendo a la vez en las constricciones derivadas del proceso de producción y en su dependencia de la actividad receptora. Así, por ejemplo, Helbo afirma que en el caso particular de la adaptación teatral, reducirla a una retórica de la adición-supresión resulta hoy difícilmente sostenible y conviene abordarla teniendo en cuenta el proceso interactivo que subyace en el paso del texto teatral al texto fílmico y que se manifiesta en la presencia de una tercera instancia: el guión (Helbo, 25). Citando a Sobel, dirá en otro momento: «No se filma una pieza de teatro sino el esfuerzo por crear un objeto, es decir, la escritura» (Helbo, 47). Este desplazamiento del interés hacia el acto de producción enfoca la adaptación como un proceso dialógico que concierne también al contexto operacional: la inserción de la obra adaptada en un contexto nuevo implica tener en cuenta los modelos culturales vigentes en éste (los cuales determinarán la aceptabilidad de la obra) y considerar sus diferencias con los vigentes en el contexto de partida (Helbo, 26).

Virginia Guarinos, en el trabajo ya citado donde lleva a cabo una exposición exhaustiva de las relaciones entre teatro y cine, aborda la cues- 
tión de la adaptación de los textos teatrales a la pantalla desde la incompatibilidad absoluta entre los lenguajes de ambos medios; ello le lleva a afirmar que el teatro filmado no existe, ya que la intervención de la cámara implica una escena profílmica no teatral sino elaborada con vistas a la construcción de una narración. En el teatro, al no ser narrativo, no pueden encontrarse similitudes de estructuras con la sintaxis de la narración fílmica; por eso, añadirá citando a Pavis, el teatro no existe como evento escénico filmado sino como temática o como escenario para una historia recompuesta o reescrita para la pantalla, por lo que decir adaptación es decir reescritura, replanteamiento de la intriga del hecho dramático y escénico (Guarinos 65-66). Por otra parte, en la organización secuencial de las escenas no se reconoce la estructura en actos ni la división de éstos en escenas; y las elipsis temporales y espaciales que en el teatro tradicional exigen cambios de escenas o de actos, en el cine se resuelven mediante fundidos, desenfoques u otros procedimientos. Es decir, en cualquier adaptación cinematográfica de un texto teatral la estructura organizativa y los procedimientos de transición espacio-temporal son totalmente filmico-narrativos y en nada se parecen a la puesta en serie y organización significante del relato dramático (Guarinos, 91).

Dejando aparte esta problemática que da cuenta de la complejidad del fenómeno y nos previene de las dificultades que presenta su caracterización, detengámonos en algunas de las diversas tipologías elaboradas para clasificar las prácticas adaptativas realizadas a partir de textos teatrales, elaboradas desde criterios diversos.

Kracauer distingue entre adaptaciones en las que se lleva a cabo una representación directa de la intriga teatral y aquellas otras en que la intriga resulta ampliada. En las primeras no se intenta explorar el mundo en torno por lo que se conserva la atmósfera claustrofóbica de la pieza teatral; se pone el acento en los personajes y en su relación mientras que los objetos inanimados y los factores ambientales tienen un papel secundario; no incluyen imagen alguna que no sirva a los fines de construcción de la historia. En las adaptaciones en que se amplía la intriga se intenta que la «realidad» participe de la acción y son posibles dos opciones: que la composición del argumento eclipsa las elaboraciones del argumento o la inversa, que las elaboraciones cinemáticas eclipsen la composición del argumento. Del primer caso cita como ejemplo Alexander Nevski, de Eisenstein, organizada como una tragedia en 5 actos; en ella los elementos cinemáticos como la batalla del lago no añaden nada a la intriga y su función es puramente estructurante, al modo de las batallas en las obras de Shakespeare que no necesitan ser vistas para producir un efecto dramá- 
Teatro y cine: un permanente diálogo intermedial

tico. El segundo caso se produce en todos aquellos filmes en que los elementos amplificadores acaban produciendo un debilitamiento de la intriga (Kracauer, 281-288).

La tipología de Helbo se basa más en la dimensión espectacular del teatro y desdeña la estrictamente literaria; distingue ,así, entre dos vías distintas de filmar el teatro: la captación directa de un espectáculo y la intervención que adapta la representación al medio fílmico. Dentro de la primera vía establece distintos grados: la grabación de una representación teatral (para archivarla u ofrecerla en diferido), la reconstitución a partir de fragmentos filmados en varias representaciones de un mismo montaje y la reconstitución creativa mediante la intervención de un discurso fílmico sobre un material escénico previo ${ }^{4}$. La otra vía consiste en la creación en la pantalla de un suceso teatral no tributario de una representación 'preestilizada', y puede alejarse en mayor o menor grado del origen teatral en función de los elementos modificados (alteración de los diálogos originales, incorporación de exteriores, etc.) hasta el punto de que el espectador no tenga constancia de él. Entre ambas opciones señala prácticas intermedias que llegan a constituir un abanico de ensayos originales e inclasificables. Aunque se pregunta sobre la «inocencia» de toda adaptación que se presente con pretensiones de objetividad respecto de la representación, ya que toda adaptáción lleva asociada una poética de la infidelidad, que tiende a construir una réplica, es decir, a elaborar otro objeto mediante la recurrencia a otro lenguaje (Helbo, 4041).

Patricia Trapero, por su parte, maneja un concepto más amplio de adaptación en el que se implican no sólo los mecanismos textuales sino también el concepto de «género»; distingue, por ello, tres posibilidades: la primera cuando el texto teatral se convierte en un guión cinematográfico respetando el género dramático correspondiente, aunque se planteen variaciones respecto a los elementos formales, al contenido o al punto de vista con relación a la historia narrada; la segunda tiene lugar cuando se aprovecha el argumento del texto teatral y se lo ubica en un género distinto o en un microcosmos cultural diferente; la tercera posibilidad se refiere a aquellos casos en que el texto teatral sirve «como excusa de secciones argumentales o configuración de situaciones o personajes contextualizadós / descontextualizados». Señala que este último caso, aunque es el que menos afecta a los mecanismos de manipulación, pone en evidencia el aprovechamiento de aspectos argumentales parciales por parte de los realizadores para hacer guiños al espectador y cumplir «una determinada función conativa respecto al original, a circunstancias ideológicas / 
de configuración de un proceso argumental o simplemente por placer» ${ }^{5}$ (Trapero, 52-53).

Citemos por último la tipología más exhaustiva propuesta por Sánchez Noriega, quien, ampliando a Helbo, considera necesario partir de una distinción previa entre adaptaciones de representaciones teatrales y adaptaciones de textos teatrales. En las primeras hay que considerar, aparte del texto literario previo (T1), una plasmación escénica del mismo (T2) sobre la cual se lleva a cabo la filmación (T3). Entre ellas, y siguiendo a Helbo, distingue entre grabación de una representación y la recreación de una representación en un plató donde se adecue el espacio teatral-escénico a las necesidades de la expresión fílmica. Respecto de las adaptaciones de textos teatrales, considera necesario distinguir entre adaptación integral (cuando el conjunto del texto teatral ha sido plasmado en el filmico $)^{6}$ y adaptación libre, cuando los elementos esenciales del texto teatral se toman como punto de partida para un guión que poseerá un alto grado de autonomía respecto s su origen teatral ya que el proceso adaptador puede operar a tres niveles: sobre el texto, sobre la organización y estructura dramática y sobre las coordenadas espacio-temporales (Sánchez Noriega, 73-75).

\section{Del cine al teatro}

Se puede afirmar que ya a partir de los años 20 comienza a producirse un movimiento inverso de influencia del cine sobre el teatro; influencia perceptible tanto en términos de escritura como de tipo técnico al nivel de la escenografía.

Respecto del primer tipo de influencia, cabe señalar cómo el teatro descubre a la par que otras artes contemporáneas el montaje cinematográfico y la filosofía subyacente al mismo de valorar las estrategias formales sobre los contenidos que éstas producen, los cuales son, al fin y al cabo, su consecuencia; piénsese que la teoría formalista de la forma «extrañante» y sus efectos desautomatizadores de nuestra percepción de la realidad es estrictamente contemporánea del momento en que el cine se afianza como medio de expresión artístico independiente. El teatro, cuya rebelión contra las imposiciones de la mímesis naturalista se había iniciạdo unas décadas antes, encuentra un sólido apoyo a esa rebelión en las teorías del montaje cinematográfico y en su principio de que la función del arte no era tanto la imitación de la realidad como el de reproducir con sus propios medios el funcionamiento de esa realidad. 


\section{Teatro y cine: un permanente diálogo intermedial}

La formulación brechtiana de un teatro épico es, sin lugar a dudas, una de las primeras consecuencias de la aplicación de las teorías del montaje al campo de la práctica escénica: su concepción del tiempo se inspira en las constricciones fílmicas, a la vez que la estética de la puesta en escena desarrolla las técnicas de focalización, puesta en cuadro, manipulación del espacio-tiempo, etc.

Respecto de la influencia en la técnica escenográfica recuérdese la integración de fragmentos fílmados en la escena que Piscator lleva a cabo en Alemania en montajes como Rasputín o El valiente soldado Schweyk; igualmente, en Rusia, Meyerhold en Les Aubes proyecta imágenes de los soldados del ejército rojo desfilando; y Eisenstein, Vertov, Pudovkin o Kulechov, quienes simultanearon sus trabajos de director de escena y realizador cinematográfico, investigaban sobre la aplicación en el teatro de procedimientos como el gran primer plano o la sobreimpresión ${ }^{7}$ a la vez que en otros países de Europa varios directores de escena utilizan la luz para vehicular una concepción de la imagen inspirada en el cinema.

Cabe hablar asimismo de influencia del cine sobre la concepción de la dramaturgia (la interpretación épica de Brecht hace emerger la opacidad del actor, su aptitud para expresar las contradicciones del mundo; por otra parte, el Actor's Studio, en el que se forman muchos actores de Hollywood desarrolla las técnicas de Stanislavski) y sobre la visión del mundo ligada a la puesta en escena (explotación en escena de las técnicas de las superproducciones cinematográficas en un intento de competir con el cine en términos de realismo). Pero sin duda, la influencia más relevante es la que afecta al universo de referencias del espectador pues es evidente que la gente del teatro ha tenido cada vez más en cuenta los nuevos hábitos perceptivos, cognitivos y epistemológicos de unos espectadores formados en el cine y en la televisión cuya experiencia de lo fragmentario, de la pluralidad -el zapping- le incitan a construir un sentido para cada signo: así son cada vez más frecuentes en escena la utilización de los efectos del ralenti, las inserciones de flash-backs del pasado, de fragmentos de conversación, de informaciones radiofónicas, de desplazamientos.bruscos de los actores, etc. (Helbo 36-38).

La recurrencia a todas estas estrategias de indudable procedencia cinematográfica, hace que se difuminen notablemente las fronteras entre representación y relato, herencia de la distinción aristotélica entre mímesis y diégesis, que se ha utilizado a menudo para delimitar los territorios de lo teatral y lo cinematográfico. Como apunta Jost, hoy en día resulta arriesgado definir lo teatral a partir de la ausencia absoluta de cualquier instancia mediadora porque, el hecho de «poner ante los ojos» implica que 
la materia dramática ha debido sufrir un proceso de selección, primero en la composición del texto y luego en la elaboración de la puesta en escena. Evidentemente, dirá, el espectador de teatro, al contrario del cinematográfico, no ve nunca exactamente lo que el director de escena pone delante de sus ojos, pues la fabricación de la mirada en el teatro es producto de un trabajo perceptivo del espectador en todos los momentos de la representación; pero el director de escena puede actuar sobre la dirección de la mirada del espectador mediante procedimientos de ostensión diversos (iluminación brutal, desplazamientos bruscos del actor, apariciones, etc.). Ello impide afrontar la distinción entre cine y teatro a partir de la oposición entre visión directa y visión inducida y obliga a abordarla en función de la existencia de diversos grados de inmersión perceptiva (Jost, 1999).

No obstante, la influencia del cine sobre el teatro no ha tenido siempre efectos dinamizadores como los descritos, que han potenciado el proceso de evolución del arte escénico en su distanciamiento del canon naturalista; en otro momentos esa influencia ha actuado en sentido opuesto como factor de involución determinando la recuperación de sus medios de expresión tradicionales. Es preciso tener en cuenta para comprender esta influencia involucionista que el cine, a comienzos de la década de los treinta, había consolidado su prestigio entre los medios intelectuales que aún lo acogían con reticencias: su lenguaje había logrado un elevado grado de perfeccionamiento y la fidelidad alcanzada en la reproducción de voces y sonidos, tras los frustrantes tanteos que siguieron a la implantación del sonoro, lo capacitaban plenamente para la adaptación de textos literarios. En esos años desarrolla géneros como la comedia cuya base es un sólido guión literario, con diálogos brillantes y una limitación considerable del espacio en que se desarrolla la acción. Ello hace posible que los comediógrafos vuelvan sus ojos hacia la filmografía de directores como Frank Capra, Ernest Lubichst o Howard Hawks, para imitar el perfecto engranaje con que se desarrollan las situaciones en sus guiones, la economía de medios con que consiguen unas impecables puestas en escena o del dinámico ensamblaje y chispeante gracia de las réplicas. El cine influye, así, sobre el teatro potenciando la calidad de sus diálogos y revitalizando, por consiguiente, sus aspectos literarios frente a los espectaculares; si a ello añadimos el sometimiento a las limitaciones del espacio único y la imposición de la narración lineal, no resulta exagerado afirmar que el cine propició una recuperación de los presupuestos de la escena naturalista. Aunque el universo que presentan estas comedias, al igual que el ofrecido por la pantalla, está siempre envuelto en un nimbo de irrealidad que hace que los espectadores lo experimenten como una dimensión inaccesible desde su universo cotidiano. 
Teatro y cine: un permanente diálogo intermedial

\subsection{Un ejemplo dr influencia cinematográfica en el teatro español}

Un caso paradigmático de esa influencia de los modelos cinematográficos sobre la escena lo constituye la producción dramática de autores como Jardiel Poncela, Edgar Neville José López Rubio, Antonio Lara («Tono») o Miguel Mihura, desarrollada en los años posteriores a la guerra civil y cuando casi todos ellos habían pasado por los estudios hollywoodenses trabajando como guionistas o adaptadores de las versiones en lengua española.

La producción de estos dramaturgos no puede ser abordada sin tener en cuenta su deuda innegable con el cine y la relación ambivalente que con él mantienen en todo momento: por una parte siguen cultivando las estrategias rupturistas que el cine había introducido en la tradición naturalista de la escena en las dos décadas precedentes (no se olvide la militancia de todos ellos en las filas de la vanguardia durante los años previos a la guerra civil) y, por otra apelan a la teatralidad recuperada por la comedia hollywoodense y en sintonía con el conservadurismo estético e ideológico que su público les demandaba.

Entre esos mecanismos de procedencia cinematográfica con los que transgreden los principios de la puesta en escena naturalista podría citarse en primer lugar la introducción de un punto de vista móvil a diferencia del único y permanente del teatro tradicional; el espectador no está ya limitado a una visión externa y objetiva sino que le es dado participar de la perspectiva de alguno (o algunos) de los personajes. El teatro intenta, así, aproximarse a la alternancia entre visión externa y visión interna sobre la que se basa la narración cinematográfica haciendo llegar a los espectadores informaciones que proceden de la percepción física o mental de alguno de los seres situados sobre la escena. El teatro dramático ha sabido utilizar a fondo esta recurrencia a la visión interna (piénsese en Arthur Miller o, en España, en Buero Vallejo), pero en la comedia se convierte, asimismo, en un poderoso recurso de comicidad. Podemos citar como ejemplo La otra orilla, de López Rubio, planteada sobre el contraste entre el privilegiado punto de vista de unos personajes que han muerto (Ana, Leonardo, Martín y Jaime) frente a la visión limitada de los vivos (Policías, Rufino, Diego, Felisa, Mauricio y el señor Roca). La noción punto de vista no ha de entenderse sólo como relativa a la visión sino también a la percepción auditiva. Así lo podemos ver en una escena otra obra de López Rubio, Celos del aire, en la que la seducción simulada de Cristina por parte de Enrique es percibida como verdadera por la pareja de adúlteros, Bernardo e Isabel, quienes no llegan a oir las palabras que aquellos pronuncian. En sentido inverso, la transferen- 
cia del punto de vista a uno de los personajes puede servir para acrecentar la confusión del espectador al hacerle compartir su mirada con un personaje carente de toda información quien asiste como testigo atónito a una situación fuera carente de toda lógica. Recuérdense al respecto el personaje de El Comprador de La venda en los ojos, de López Rubio o el del periodista Martínez de Tú yo somos tres, de Jardiel.

Consecuencia de esa visión subjetiva es la incorporación al universo de la escena de «realidades» no existentes o de seres irreales producto del sueño, la alucinación o a imaginación de alguno de los personajes. Con ello se abre la posibilidad de ampliar a la historia narrada con otras dimensiones de la realidad que son asumidas sin ningún problema por el espectador como verosímiles. Citemos como ejemplo las escenas absurdas que constituyen casi la totalidad del primer acto de El caso de la mujer asesinadita, de Mihura (escrita en colaboración con Álvaro de Laiglesia), que se explican luego como un sueño premonitorio de la protagonista. En la obra del propio Mihura encontramos otro ejemplo del mismo tenor, aunque en este caso no explicitado: la escena surreal con la que comienza el II acto de Tres sombreros de copa, en el que los extraños personajes que pueblan el escenario y cuya presencia carece de toda lógica ${ }^{8}$, corresponden a una alucinación de Dionisio quien se halla bajo los efectos de la embriaguez y en un estado plenamente orgiástico. Podría citarse, asimismo, Romeo y Julieta Martínez de «Tono», en donde los acontecimientos absurdos que presenta la fábula y los diálogos no menos absurdos de de los personajes se descubren al final como producto de un sueño de la protagonista. En otros casos, la dimensión irreal evocada sobre el escenario no es producto de la alucinación ni del sueño sino de la imaginación del personaje, como sucede en La vida en un hilo, de Neville, en la que las escenas correspondientes al plano de la realidad alternan con otras que corresponden a lo imaginado por Mercedes, la protagonista, quien especula sobre el curso tan distinto que hubiera llevado su existencia de haberse casado con Miguel en lugar de con Ramón. En el caso de los personajes irreales (el Vicediablo en Veinte añitos y la Dama de gris en Adelita, ambas de Neville; las Voces celestes en Nunca es tarde, de López Rubio, Leonardo en Las cinco advertencias de Satanás, de Jardiel Poncela), el contexto humorístico en que tales apariciones se producen mitigan su inverosimilitud, que puede ser aceptada como uno de los rasgos constitutivos del género. Recuérdense las declaraciones de Jardiel relativas a la necesidad de incorporar la fantasía y la inverosimilitud a la escena ${ }^{9}$ y que todos los miembros del grupo parecieron asumir como una propuesta programática, si bien la iconoclastia inherente al teatro de Jardiel y del primer Mihura se va mitigando tras la prematura desaparición de 
Teatro y cine: un permanente diálogo intermedial

aquél para dejar paso a un ternurismo combinado con cierta dosis de poesía.

Y no puede dejar de citarse la fragmentación y multiplicación del espacio escénico, que deja de estar sometido a las limitaciones derivadas del decorado estático tradicional. Bien es verdad que la tendencia a esa fragmentación es anterior al cine y comienza a ser puesta en práctica por las corrientes expresionistas de comienzos de siglo aprovechando las posibilidades que brinda la iluminación eléctrica; pero el dinamismo de la narración cinematográfica, una vez afianzado sus medios expresivos propios, contribuye, sin duda, a la nueva concepción del espacio escénico, común a la mayor parte de las piezas que se inscriben dentro de cualquiera de las múltiples corrientes de la reacción antinaturalista ${ }^{10}$. El caso más paradigmático lo constituye, sin duda, La vida en un hilo, de Edgar Neville, concebida originalmente como un guión cinematográfico, en la que el «espacio del tedio», el interior de casa ranciamente burguesa en el que se desarrolla la existencia real de Mercedes, alterna con los diversos espacios en los que podrían haber tenido lugar los acontecimientos que evoca a medida que se va imaginando el curso que hubiera seguido su vida de haberse casado con Miguel en lugar de con Ramón.

Junto a tales elementos transgresores del naturalismo tradicional, coexisten en la obra de estos dramaturgos otros que son clara reafirmación del mismo, ahora avalados por el prestigio del cine. El perfeccionamiento de los mecanismos reproductores de la palabra y del sonido supuso, como se ha señalado más arriba; una nueva etapa en la andadura del cine, cuyos productos, prestigiados por la base literaria, ejercerán ahora una influencia conservadora sobre el teatro convirtiéndose en modelos para la construcción de piezas dramáticas. En el grupo de comediógrafos que nos ocupa (cuya experiencia como guionistas y dialoguistas en los estudios hollywoodenses no hay que olvidar), dicha influencia pesa de modo decisivo cuando se enfrentan a la necesidad de elaborar de un teatro ceñido a los esquemas tradicionales que exigía el conservadurismo de su público, pero dotado, a la vez, del grado de innovación y brillantez suficientes para distanciarse de las viejas propuestas que aún sobrevivían sobre los escenarios. Entre los elementos de ese teatro, concebido a través del cine, puede destacarse ante todo el perfecto engranaje de la acción, que responde en la mayor parte de estas comedias a una planificación de rigor matemático tras la que no resulta difícil percibir la influencia de la comedia hollywoodense de los años 30 y 40 (Hawks, Lubitsch, Capra): la limitaciones espaciales y temporales de las piezas de López Rubio, Neville, Mihura o Jardiel tienen muy poco que ver con las de la comedia tradicional (muchas veces consecuencia de la penuria escénica) y responden 
a una autolimitación consciente del autor, que las afronta como un desafío.

A ello hay que añadir el humor de base verbal, pródigo en sutilezas que demuestran manejo hábil de los recursos de la ironía; se trata de un lenguaje sin estridencias, muy alejado del chiste grueso del teatro de humor precedente y de su recurrencias a los retruécanos, dilogías, hipérboles y otros recursos igualmente fáciles. Tras él, se perciben, en cambio, las huellas de la revolución vanguardista cuyos hallazgos contribuyen a que el disparate aparezca mitigado por el lirismo o que la poesía constituya el grano de locura suficiente para servir como antídoto contra el racionalismo que gobierna la puesta escena. En otros casos nos encontramos con el humor absurdo de réplicas desconcertantes, que ya comenzaron a cultivar Mihura y «Tono» en las páginas de La ametralladora y en el que no resulta difícil reconocer la influencia de los hermanos Marx.

Ese humor de base verbal no resulta incompatible con un humor situacional en el que se detentan las huellas de algunos de los maestros de cine mudo (Chaplin, Buster Keaton. Harold Lloyd). En el teatro humorístico precedente contra el que estos autores reaccionan dicho tipo de comicidad quedaba, por lo general, limitada a los trazos gruesos de lo caricaturesco, mientras que ahora el cine les ha enseñado a manejar con sutileza los gestos y movimientos y a potenciar sus efectos evitando reducirlos a una utilización exclusivamente mecanicista. Puede uno darse cuenta de ello a la vista de la importancia que adquiere en cualquiera de estas comedias el texto secundario, en el cual amplios segmentos están dedicados a la descripción de los aspectos kinésicos y proxémicos de la puesta en escena. Recuérdese, entre los muchos ejemplos posibles, el juego escénico, de base fundamentalmente kinésica, que provoca de decisión de los dueños de la casa de Celos del aire de López Rubio, de ignorar a la pareja de inquilinos con quien comparten las estancias comunes y los servicios del mayordomo.

Por último, hay que mencionar el sentido lúdico de la existencia que caracteriza a los personajes pobladores de este universo, el fair play que suele regir sus actuaciones. Tal rasgo puede derivarse, en parte, del ambiente cosmopolita propio en el que se desenvuelven y que no es muy distinto del que el teatro precedente presentaba en un género tan característico del mismo como la «alta comedia»; pero no se trata en modo alguno del universo acartonado y artificioso de aquélla, en donde los tipos y las conductas eran producto de las convenciones de un código estereotipado, sino que los personajes de este teatro, a semejanza de los de la comedia cinematográfica norteamericana, habitan un mundo burbujean- 
Teatro y cine: un permanente diálogo intermedial

te en donde los patrones sociales y morales parecen siempre a punto de ser socavados por un toque de irracionalidad. Se trata, evidentemente, de unas obras de evasión en el que el estatus elevado de sus protagonistas es condición necesaria para la concepción lúdica de la existencia inherente a un género que propone frente a la gris cotidianidad de los espectadores un mundo ideal que sirva como lenitivo momentáneo a sus frustraciones ${ }^{11}$.

En este sentido es en el que este teatro se muestra heredero más directo del cine. Todo él remite a un mundo irreal, pero de una irrealidad basada no tanto en la alucinación, en la incorporación de dimensiones «extrerreales» de la existencia; como en el exceso de perfección de lo que se ofrece como trasunto de la realidad ${ }^{12}$. Recuérdese que el carácter ambivalente de las imágenes cinematográficas estriba en su capacidad de conjugar la sobredosis de realismo que presentan sus seres y sus objetos con el carácter fantasmagórico de los mismos; un mundo que puede parecer más real que la realidad pero que, paradójicamente, está a la vez hecho de la materia evanescente de nuestros sueños y resulta tan inaccesible como ellos. Ese universo de la pantalla, especialmente el ofrecido por las comedias de directores como los citados, es el que reproducen sobre el escenario las piezas de nuestros autores: la realidad está ahí en todo su esplendor de su perfección, pero esa misma perfección es lo que la que multiplica su distancia frente al espectador y le confiere el nivel de irrealidad de los sueños. La perfección de la mímesis conlleva, paradójicamente, la condición clausurada del universo reproducido.

\section{Para concluir}

El fecundo intercambio intermedial que nos ha ocupado en las páginas precedentes continúa manifestándose en síntomas diversos como la asiduidad de los montajes teatrales llevados a cabo por realizadores cinematográficos (recuérdense en nuestro país los casos de Pilar Miró, Jaime Chávarri o Gonzalo Suárez) o la incorporación a la escena de elementos claramente tributarios de una estética cinematográfica con lo que se ha verificado plenamente la afirmación de Meyerhold sobre las posibilidades de dinamización que la estética del cine podía aportar a la escena (García-Abad, 341-342). Una de las manifestaciones más sorprendentes, por lo que supone de novedoso, de este diáloge la constituye la insistente realización de espectáculos teatrales a partir de éxitos cinematográficos previos; en esta práctica está, sin duda, el intento de la industria teatral de captar nuevos espectadores, utilizando el incentivo ci- 
nematográfico (y la popularidad de actores procedentes de este medio o del televisivo) para atraer a las salas a un público especialmente joven y carente de experiencia como receptor de espectáculos teatrales.

Francisca Vilches, que ha reflexionado sobre la frecuencia actual de este fenómeno en los escenarios españoles, lo explica ante todo por razones económicas, ya que la elección recae por lo general sobre películas que han conseguido un éxito de taquilla notable, indistintamente de que su origen sea un texto narrativo (La naranja mecánica, de Kubrick; Sola en la oscuridad, de Terence Young; La heredera, de William Wyler) o teatral (Crimen perfecto, de Hitchcok; La huella, de Mankiewicz; ¿Quién teme a Virginia Woolf?, de Mike Nichols); aunque la elección de los empresarios teatrales parece decantarse especialmente por los filmes musicales de éxito (muchos de los cuales fueron en su origen espectáculos teatrales): West Side Story, El hombre de la Mancha, Grease, La bella y la bestia, etc. Entre las razones que llevan a la industria teatral a este tipo de propuestas estaría fundamentalmente el carácter comercial de las producciones, varias de las cuales son repetición de montajes de espectáculos musicales llevados a cabo en escenarios de Londres o Nueva York o rescate de thrillers o comedias exitosas (Crimen perfecto, de Hitchcock, La tentación vive arriba, de Wilder) pero el público destinatario de este tipo de propuestas no es unitario por lo que, en otros casos, hay que pensar hasta que punto sido determinante la medida en que los textos elegidos abordan temas que sintonizan con las preocupaciones de los espectadores actuales: montajes realizados a partir de películas como $E l$ verdugo, de Berlanga, El hombre elefante, de David Lynch, Magnolias de acero, de Herbert Ross, La naranja mecánica, de Kubrick, entre otros muchos, no van dirigidos, evidentemente, a un público que busca en los escenarios la evasión sino a otro más concienciado con la realidad de su entorno político y social. (Vilches, 390-394).

Cada uno de estos casos exigiría, no obstante, un análisis detenido para averiguar las razones que han llevado a la elección del filme, interrogándose sobre el horizonte de expectativas del público que acude a presenciar tal tipo de montajes, sobre su conocimiento del filme de partida, sobre las semejanzas y diferencias entre los contextos de recepción de uno y otro, etc.; y también, obviamente, para detectar los trasvases de los procedimientos de expresión cinematográficos al medio escénico y las transformaciones experimentadas por los mismos en su adecuación a éste.

Como conclusión, cabe sostener que el proceso de interinfluencias continua plenamente operativo en ambas direcciones, si bien los objetivos perseguidos puedan diferir en cada caso: de modo general, cabe afirmar 
que la «teatralización» actual del cine suele responder a un intento de afirmación elitista, al propósito de alejarse de la degradación experimentada por la estética del realismo, por la devaluación del «efecto realidad» en una cultura dominada por la imagen y proponer frente a ella un ejercicio metaficcional mediante el que las marcas de la teatralidad se convierten en estrategias propiciadoras de la reflexión sobre el propio discurso $^{13}$; en cambio, cuando el teatro bebe de las fuentes cinematográficas lo hace, por lo general, con un propósito de signo opuesto: el de aprovechar el tirón popular del cine para atraer el interés de los públicos más amplios de aquél. Aunque esta afirmación cabe ser matizada, ya que desde hace varias décadas, el autor o director de teatro difícilmente pueden sustraerse a la influencia del cine a la hora de escribir su texto o plantear sus propuestas escénicas. Como señala De Marinis (quien califica al teatro actual como «postcinematográfico») un dramaturgo no puede ignorar las enormes mutaciones que la irrupción de los nuevos medios ha producido en el sistema del espectáculo y ni las modificaciones que debido a su influjo se han verificado en los gustos y en la percepción del espectador (De Marinis, 193).

Este diálogo entre cine y teatro se ha ampliado con la intervención de un tercer interlocutor, la televisión, que ha supuesto un replanteamiento de los presupuestos teóricos manejados hasta ahora con el objeto de abordar los problemas que su irrupción plantea. Referirse a las aportaciones de la bibliografía (que no deja de incrementarse) sobre teatro y televisión y sobre las peculiaridades de ésta con relación al cine a la hora de abordar los textos escénicos desbordaría los límites de estas páginas; baste citar algunos de los trabajos más relevantes entre los que destacan libros como los de Bettetini (1986), Helbo (1989) o Guarinos (1992), o algunos de los artículos publicados recientemente en el ámbito español como los de Amestoy (1998), Espín Templado (2002) o Vázquez Medel (2002) entre otros.

\section{Notas}

1 Los grandes directores del movimiento como Ernst Lubitsch, Paul Muni, F.W. Murnau o Fritz Lang se habían formado a las órdenes de Max Reinhardt y los actores que protagonizaron sus filmes procedían en su mayoría de los escenarios (Hueso, 50-51). Para Relinger, las modalidades enunciativas de El gabinete del doctor Caligari (1919) de Robert Wiene, filme emblemático de esa época, son un elocuente resumen del trasvase de las estrategias del discurso teatral a la pantalla: estructura en 6 actos, estilización total del decorado compuesto enteramente de telas pintadas, espacio cerrado, interpretación exagerada de los actores, personajes tipo, planos fijos, cámara inmóvil y frontal, apertura y cierre de la imagen mediante iris ondulado a modo de telón, etc. (Relinger, 133). 
2 Guarinos señala a este respecto que lo teatral del discurso fílmico no está en las supresiones o añadidos a la obra original sino en las "operaciones constructivas referentes al propio discurso fílmico, a su puesta en escena, su puesta en cuadro y su puesta en serie»; por ello, dirá, la imitación se produce en el interior de los procedimientos fílmicos, haciéndolos cercanos a procedimientos teatrales" (Guarinos, 70).

3 Frente a la estrategia de la exacerbación de la teatralidad, Cornago señala la opuesta, aunque complementaria, de su disolución, observable en el efecto verdad que buscan muchos realizadores desde los años 60 (nouvelle vague francesa, free cinema inglés) hasta el movimiento Dogma que lidera en la actualidad el danés von Trier y cuyo objetivo es devolver al cine la realidad inmediata secuestrada por las elaboradas ficciones del cine hollywoodense (Cornago, 554).

4 Cita al respecto el Marat-Sade, de Peter Brook, filmado con los actores de la Royal Shakespeare Company que lo habían llevado a escena, en un estudio y utilizando dos cámara móviles.

${ }^{5}$ Entre los ejemplos que aduce de esta última opción están el monólogo de Hamlet y el de Shylock (El mercader de Venecia) utilizados por Lubitsch en To be or not to be para trasladar situaciones sentimentales e ideológicas específicas.

${ }^{6}$ En tal caso, apunta cómo la solución más tradicional ha sido la de camuflar el origen teatral del texto mediante técnicas de "aireamiento" que proporcionen un mayor realismo; aunque algunos realizadores han optado por la creación de un relato fílmico que muestra la puesta en escena de una obra de teatro: se trata entonces de un relato de segundo orden dentro de la película: Enrique $V$, de Olivier y Vania en la calle 42 , de Malle serían ejemplos de esta estrategia.

7 Conviene señalar a este respecto la posibilidad de la primacía del uso del montaje en el teatro por parte estos artistas rusos y su utilización posterior en el cine. Virginia Guarinos afirma, así, que el montaje de atracciones de Eisenstein procede «de sus experiencias teatrales previas a las cinematográficas en las que intentaba conseguir el shock en el espectador a través del impacto visual de números sueltos", experiencias que fueron llevadas a cabo también por dramaturgos como Maiakovsky o Meyerhold (Guarinos, 37-38).

8 «Hay muchos personajes en escena. cuantos más veamos más divertidos estaremos. La mayoría son viejos extraños que no hablan. Bailan solamente, unos con otros, o quizá, con alegres muchachas que no sabemos de donde han salido ni nos debe importar demasiado. Entre ellos hay un viejo lobo de mar vestido de marinero... Hay un indio con turbante, o hay un árabe. En fin, un coro absurdo y extraordinario que ambientará unos minutos la escena, ya que a los pocos minutos de levantarse el telón, irán desapareciendo por la puerta de la izquierda» (p. 67 de la edición de Cátedra, Madrid, 1979).

9 «El incorporar la fantasía y la inverosimilitud a la escena era el blanco al que, desde mis primeros ensayos, dirigí las flechas, haciendo diana unas veces, clavándolas en un anillo exterior otras y perdiéndolas en el vacío cuando fallaron los nervios o el pulso. (...) $\mathrm{Y}$ en todas las comedias que he producido hasta el presente, incluso en aquellas no susceptibles de incluirse en el grupo de las "sin corazón", se encuentra la fantasía -la imaginación, la inverosimilitud- presidiendo el tema, la acción, los tipos y el diálogo, conducta, fin y objeto que pienso guardar asimismo fielmente en el futuro. Pues ¿valdría la pena sentarse ante una mesa, dispuesto a producir una fábula teatral sin haber contado previamente con edificarla elevándola hacia lo fantástico? (...) Lo inverosímil es el sueño. Lo vulgar es el ronquido. La Humanidad ronca. Pero el artista está en la obligación de hacerla soñar. O no es artista». (Del prólogo a Los habitantes de la casa deshabitada, O.C. vol. II, Barcelona, AHR, 1970, $6^{\text {a }}$ ed., pp. 501-502). 


\section{Teatró y cine: un permanente diálogo intermedial}

10 Incluso algún autor de los más representativos del naturalismo escénico como es Benavente, intenta en alguna ocasión romper con el estatismo del decorado tradicional multiplicando los cuadros gracias a la contribución de los efectos luminosos. Recuérdese la obra Vidas cruzadas (1929), calificada significativamente por el autor de "cinedrama».

11 Este motivo se encuentra a menudo tematizado en varias de las piezas de los autores que nos ocupan, en las que el argumento gira en torno a la pretensión de alguno de los personajes de construirse un mundo a la medida de sus deseos en el que vivir aislado de una realidad que les resulta insoportable; recuérdese a la protagonista de La venda en los ojos, de López Rubio o al Edgardo de Eloísa está debajo de un almendro, de Jardiel. Dicho motivo es también el eje argumental de La viuda es sueño, de "Tono" (escrita en colaboración con Jorge Llopis), aunque en este caso son los personajes que rodean a Socorro, la protagonista, quienes se encargan de «adecuar» la realidad para evitarle el choque que pudiera suponerle su incorporación a la vida tras casi cien años dormida.

12 Esta afirmación cabe ser matizada en el caso de "Tono", en cuyas obras (especialmente en las escritas en colaboración con Jorge Llopis) aparecen a menudo referencias en clave humorística a las duras circunstancias de la España de la inmediata postguerra: el estraperlo, la carestía de la vida, las restricciones en el suministro de agua o en el de fluido eléctrico constituyen la base de varios de los chistes insertos en los diálogos.

${ }_{13}$ Conviene insistir en que, por el contrario, cuando el cine pretende la captación de públicos mayoritarios, sus aproximaciones al teatro suelen proceder llevando a cabo una naturalización a fondo del universo artificioso que presentan los textos de partida y una eliminación de todos los elementos susceptibles de cuestionar la verosimilitud. Véase al respecto mi trabajo sobre esta cuestión (Pérez Bowie, 2004b).

\section{Bibliografía}

ABUín, Ángel (2001): «Filmicidad y teatralidad. Aspectos comparados de la recepción espectacular», en C. Becerra et al. (eds.), Lecturas: Imágenes, Vigo, Universidad, pp. $23-$ 51.

Amestoy, Ignacio (1998): «La encrucijada de la televisión y el teatro», Primer Acto, 273, II, pp. 84-94.

ARISTARCO, Guido (1968): Historia de las teorías cinematográficas, Barcelona, Lumen.

BAZIN, André (1997): Qu'est ce que le cinéma?, Paris, Les Editions du Cerf.

BetTETINI, Gianfranco (1986): La conversación audiovisual, Madrid, Cátedra.

BROOK, Peter (1994): La puerta abierta. Reflexiones sobre la interpretación y el teatro, Barcelona, Alba Editorial.

CORNAGO BERNAL, Óscar (2001): «Dialogos a cuatro bandas: teatro, cine, televisión y teatralidad", en J. Romera Castillo (ed.), Del teatro al cine y la televisión en la segunda mitad del siglo XX, Madrid, Visor, pp. 549-559.

EsPín TEMPlado, Pilar (2002): “Pautas teórico.prácticas para el análisis semiótico de obras teatrales en televisión", en J. Romera Castillo (ed.), Del teatro al cine y la televisión en la segunda mitad del siglo XX, Madrid, Visor, pp. 561-569.

GARCÍA-ABAD, Teresa (2002): "La profecía meyerholdiana: hacia la cinematización de la escena", en J. Romera Castillo (ed.), Del teatro al cine y la televisión en la segunda mitad del siglo XX, Madrid, Visor, pp. 341-350.

GuARINOS, Virginia (1992): Teatro y televisión, Sevilla, Centro Andaluz de Teatro y Alfar. 
- (1996): ): Teatro y cine, Sevilla, Padilla Libros.

Helbo, André (1989): Teoría del espectáculo. El paradigma audiovisual, Buenos Aires, Galerna.

- (1997): ): L'adaptation. Du théâtre au cinéma. Paris: Armand Colin.

HUESO, Ángel Luis (2001): "El referente teatral en la evolución artística del cine», $A L E C$, vol. 26 , issue 1 , pp. $45-61$.

JoST, François (2000): «Théâtre et cinéma classiques français. Du théâtre a l'image», conferencia en el encuentro sobre Cine y teatro clásico en Festival de Almagro (copia cedida por el autor).

KraCAUER, Sigfried (1989): Teoría del cine. Barcelona: Paidós.

LyOTARD, Jean François (1981): Dispositivos libidinales, Madrid, Fundamentos.

PÉREZ BowIE, José A. (2004a): Realismo teatral y realismo cinematográfico. Las claves de un debate (España 1910-1936), Madrid, Biblioteca Nueva.

- (2004b): : «Las servidumbres naturalistas del cine (Sobre algunas adaptaciones cinematográficas recientes de textos teatrales 'problemáticos')", en W. Floeck y $\mathrm{M}^{\mathrm{a}}$ Francisca Vilches (eds.), Teatro y Sociedad en la España actual, Frankfurt am Main, Vervuert, pp. 283-302.

RELINGER, Jean (1992): "La théâtralité au cinéma", en Anne Larue (ed.), Théâtralité et genres littéraries, Poitiers, Publications de La Licorne, pp. 133-139.

SÁNCHEz NoRIEGA, José Luis (2000): De la literatura al cine. Teoría y análisis de la adaptación, Barcelona, Paidós.

Trapero, Patricia (2002): "Del teatro al cine. Algunas reflexiones acerca del tema", en J. Romera Castillo (ed.): Del teatro al cine y la televisión en la segunda mitad del siglo $X X$, Madrid, Visor, pp. 47-62.

VÁZqUez MEDEL, Manuel A. (2002): “Adaptaciones cinematográficas y televisivas de obras teatrales" en J. Romera Castillo (ed.), Del teatro al cine y la televisión en la segunda mitad del siglo XX, Madrid, Visor, pp. 179-191.

VILCHES DE FrUTOS, Ma Francisca (2001): “La captación de nuevos públicos en la escena contemporánea a través del cine", $A L E C$, vol. 26, issue 1, pp. 383-401. 